\title{
Evaluation on the physicochemical properties and mineral contents of Averrhoa bilimbi L. leaves dried extract and its antioxidant and antibacterial capacities
}

\author{
Ade Chandra IWANSYAH ${ }^{1 *}$ (D), Dewi DESNILASARI ${ }^{2}$ (D), Wawan AGUSTINA ${ }^{2}$, Devry PRAMESTI ${ }^{2}$, \\ Ashri INDRIATI ${ }^{2}$ (D), Nur Kartika Indah MAYASTI $^{2}$, Yusuf ANDRIANA² ${ }^{\mathbb{D}}$, Faridah Binti KORMIN ${ }^{3}$ (D)
}

\begin{abstract}
This study aimed to evaluate the physicochemical characteristics and mineral contents of dried extract of Averrhoa bilimbi and its antioxidant and antibacterial properties. Dried extracts leaves powder of $A$. bilimbi were analysed for its physicochemical properties and mineral compositions. The antioxidant and antibacterial capacities of extracts were determined by the 1,1-diphenyl-2-picrylhydrazyl (DPPH) assay and the disc diffusion method respectively. The functional groups from active compounds were identified by Fourier Transforms Infrared Spectrophotometer (FTIR). Physicochemical characteristics of A. bilimbi dried extracts, including $\mathrm{pH}$ and total acids dissolved in water and ethanol solvents, showed negligible differences. The dried leaves powder of $A$. bilimbi was rich in carbohydrate, protein, and ash contents. It also exhibited essential minerals in which potassium was the highest content. Compared to water, ethanol extract showed more scavenging property against DPPH (82.82 mg GAE/g DW) and gave a more inhibitory effect on the growth of Salmonella sp., Escherichia coli, and Staphylococcus aureus. The FTIR spectra showed phenolic compounds might be associated with the antioxidant and antibacterial activities of this extract. A. Bilimbi leaves are promising a source for the development of functional food to prevent diseases related to stress oxidative and bacterial infections.
\end{abstract}

Keywords: Averrhoa bilimbi; antioxidant property; antimicrobial activity; physicochemical characteristics; flavonoids.

Practical Application: This research is preliminary stage in investigating of antioxidant and antibacterial activities of $A$. bilimbi. After pass further stages such as in vivo, preclinical, and clinical tests this plant could be used treat diseases related anti-oxidative stress and bacterial infections, and as an ingredient for functional food product development.

\section{Introduction}

The search for newer natural antioxidant and antimicrobial agents, especially based on plant origin, has become important issue in many pharmaceutical industries and laboratories. Plant extracts and different sources of natural matrices have been reported to have antioxidant and antimicrobial activities. Averrhoa bilimbi L. (Indo: "Belimbing Wuluh"), family Oxalidaceae, is used in a traditional medicine to cure some diseases such as cough, sprue, rheumatism, toothache, stomach ache, and diarrhoea (Alhassan \& Ahmed, 2016). Several studies on the utilization of A. Bilimbi have been carried out. For example, its leaves have been used to develop antibacterial agents (Pendit et al., 2016) and to treat skin diseases (Saputra \& Anggraini, 2016). The leaves of $A$. bilimbi showed strong anticoagulant effect on diabetic rats (Sales et al., 2018). Additionally, the methanolic extract of $A$. bilimbi leaves possessed moderate analgesic and antiinflammatory properties (Miraj et al., 2019).

Some phenolic compounds from A. bilimbi such as tannins, saponins, flavonoids, and alkaloids have been reported (Ernawati, 2016). The leaves of $A$. bilimbi have also reported to possess potentially compounds including flavonoids (Kurian et al., 2018). Many studies have been carried out to utilize phenolic and flavonoid compounds as antioxidant and antibacterial agents. Phenolic acids, for example, benzoic, vanillic, sinapic, and p-hydrouxy benzoic acids and flavoboid compounds including quercetin, rutin, kaemferol have been reported to exhibit antioxidant and antibacterial activities (Rice-Evans et al, 1997; Andriana et al., 2019a).

Commonly, biological active compounds from plant's matrix can be separated by extraction technique (Andriana et al., 2019b). One of the most popular extraction methods to separate active compounds from plant matrix is maceration. In this technique, destruction of the cell wall and membrane would happen, causing secondary metabolites to escape from the cytoplasm and dissolved to the solvent (Pendit et al., 2016).

Active component from plant matrix is important factor to develop of a functional food or therapeutically drug. Moreover, in functional food development, another factor for example nutritional properties of plant is necessary to elaborate before conduct food formulation (Jones \& Jew, 2007). One of nutritional properties of food source known as trace element is mineral. Minerals are known to be required to support human biochemical processes by serving structural and functional roles as well as electrolytes. To the best of our knowledge, mineral contents of 
A. bilimbi leaves have not been reported. Moreover, information about antioxidant and antimicrobial capacities of A. bilimbi leaves extracts is also still limited. Thus, this study was conducted to evaluate physicochemical characteristics and mineral contents of A. bilimbi leaves dried extracts, and its antioxidant and antibacterial properties. The active functional groups responsible to the biological activities tested were also presented.

\section{Materials and Methods}

\subsection{Plant materials and reagents}

The fresh leaves of Averrhoa bilimbi L. were collected on May-August 2019 in Dawuan District, Subang city, Indonesia. The samples were then authenticated in Herbarium Bogoriense Indonesian Institute and the voucher specimen (AB20207215) was deposited at Laboratory of Food and Agro Chemistry, Research Center for Appropriate Technology. Gallic acid, quercetin, aluminium chloride, ethanol, sodium hydroxide, sodium carbonate, Folin-Ciocalteu's phenol, 1,1-diphenyl 2-picrylhydrazyl (DPPH) were obtained from Sigma-Aldrich Pte Ltd., Singapore. All reagents used are an analytical grade.

\subsection{Preparation plant powder and extracts}

The fresh leaves of $A$. bilimbi were washed by tap water, air dried, and finally dried using a tray dryer at $45^{\circ} \mathrm{C}$ for 4 hours. The powder $(50 \mathrm{~g})$ was then soaked in distilled water or $96 \%$ ethanol $(500 \mathrm{~mL})$ with ratio 1:10 (w/v) for 24 hours by maceration methods (3 times). After that, the filtrate was concentrated, weighed, and dried at $50^{\circ} \mathrm{C}$ by a rotary evaporator (Rotavapor R-300 Buchi, Flawil, Switzerland). The dry crude extracts were stored in air-tight container and kept in a refrigerator $\left(4^{\circ} \mathrm{C}\right)$ for further analysis (Iwansyah et al., 2019).

\subsection{Determination of physicochemical properties of A. bilimbi leaves dried extracts}

Physicochemical properties viz., $\mathrm{pH}$, yields, total solids, total acid titration, and colour were analyzed following the methods reported previously (Association of Official Analytical Chemist, 1990).

\subsection{Determination of mineral contents of A. bilimbi leaves powder}

The digestion and minerals analyses of A. bilimbi L. leaves powders were measured by atomic absorption spectroscopy (GBC $933 \mathrm{AA}$, Australia) following the method reported previously (López-López et al., 2020).

\subsection{Determination of total phenolic contents}

The total phenolic contents of $A$. bilimbi leaf extracts were determined by using a Folin-Ciocalteu assay with minor modification (Waterman \& Mole, 1994). The measurement of sample was conducted at $\lambda=760 \mathrm{~nm}$ against the blank using a spectrophotometer (SHIMADZU UV-1900, Tokyo, Japan).

\subsection{Determination of total flavonoid contents}

The total flavonoid contents of $A$. bilimbi leaf extracts were determined by using the aluminium chloride assay as reported previously (Meda et al., 2005). Measurement against the blank was carried out by a spectrophotometer (SHIMADZU UV-1900, Tokyo, Japan) at wavelength $(\lambda)=415 \mathrm{~nm}$.

\subsection{Antioxidant assay}

The antioxidant activity of $A$. bilimbi leaf extracts was measured by using the 1,1-difenil-2-pikrilhidrazil (DPPH) as reported previously with slight modification (Kumaran \& Kuranakaran, 2007). The measurement against the blank was carried out by a spectrophotometer (SHIMADZU UV-1900, Tokyo, Japan) at wavelength $(\lambda)=517 \mathrm{~nm}$.

\subsection{Antibacterial assay}

Antibacterial activities of A. bilimbi leaf extracts were determined by using the disc diffusion method (Chan et al., 2011). Our research using Escherichia coli (Migula) Castellani and Chalmers (ATCC ${ }^{\oplus} 11775^{\mathrm{Tm}}$ ), Salmonella enterica subsp. enterica (ex Kauffmann and Edwards) Le Minor and Popoff serovar Urbana (ATCC ${ }^{\otimes} 9261^{\mathrm{m}}$ ) and Staphylococcus aureus subsp. aureus Rosenbach (ATCC $\left.{ }^{\circledR} 12600^{\mathrm{rm}}\right)$. A volume $1 \mathrm{~mL}$ inoculum containing final population of $1.45 \times 10^{8} \mathrm{CFU} / \mathrm{mL}$ (S. aureus), $1.65 \times 10^{8} \mathrm{CFU} / \mathrm{mL}$ (E. coli), or $1.24 \times 10^{8} \mathrm{CFU} / \mathrm{mL}$ (Salmonella $s p)$ was pipetted in a medium Shimerile agar $(15 \mathrm{~mL})$ to sterilized petri dish $90-\mathrm{mm}$. The sample $(10 \mu \mathrm{L}, 50 \mathrm{mg} / \mathrm{mL})$ was dropped to sterile paper disc (sized $6-\mathrm{mm}$ ) and incubated at $37^{\circ} \mathrm{C}$ for 24 hours. Commercial antibiotics, cefadroxill and amoxilin, were used as positive control a dose of $3.8 \mathrm{mg} / \mathrm{ml}$ for both antibiotics.

\subsection{Identification of Chemical Functional Group by Fourier transforms infrared spectrophotometer (FTIR)}

Dried powder, ethanol and water extracts of A. bilimbi leaves were used for FTIR analysis. The samples were loaded directly in FTIR spectroscope (Bruker A7.8), with a scan range from 450 to $4000 / \mathrm{cm}$ and each sample was scanned in triplicate.

\subsection{Statistical analysis}

The statistical analysis was performed by one-way analysis of variance (ANOVA) using Minitab ${ }^{\circledR}$ 16.2.3 (copyright $\odot 2012$ Minitab Inc., USA). The data were presented in means \pm standard deviations (SD) $(n=3)$. The significant difference of data was determined by Independent Sample t-test $(\alpha=5 \%)$.

\section{Results and Discussion}

\subsection{Physicochemical properties and mineral contents of A. bilimbi leaves dried extracts}

Physicochemical properties and mineral of A. bilimbi leaves dried extracts are displayed in Tables 1 and 2. In physicochemical analyses, ethanol extract showed negligible effects on the $\mathrm{pH}$ and total acid compared to water extract. The $\mathrm{pH}$ values of water and ethanol extracts of $A$. bilimbi leaves were 6.47 and 6.30, respectively. 
Table 1. Physicochemical and colour characteristics of $A$. bilimbi leaves dried extracts.

\begin{tabular}{lcc}
\hline \multicolumn{1}{c}{ Constituent } & Water extract & Ethanolic extract \\
\hline $\mathrm{pH}$ & $6.47 \pm 0.00^{\mathrm{a}}$ & $6.30 \pm 0.01^{\mathrm{b}}$ \\
Yield (\%) & $43.28 \pm 0.25^{\mathrm{b}}$ & $50.87 \pm 0.43^{\mathrm{a}}$ \\
Total solid ( ${ }^{\circ}$ Brix) & $0.50 \pm 0.00^{\mathrm{b}}$ & $18.40 \pm 0.02^{\mathrm{a}}$ \\
Total acid titrable (\%) & $0.0066 \pm 0.010^{\mathrm{b}}$ & $0.0086 \pm 0.015^{\mathrm{a}}$ \\
Color: & & \\
$L^{*}$ & $56.897 \pm 1.008^{\mathrm{a}}$ & $47.872 \pm 0.003^{\mathrm{b}}$ \\
$a^{*}$ & $-1.221 \pm 0.141^{\mathrm{b}}$ & $-3.717 \pm 0.012^{\mathrm{a}}$ \\
$b^{*}$ & $16.419 \pm 0.606^{\mathrm{a}}$ & $10.373 \pm 0.010^{\mathrm{b}}$ \\
hue & $0.002 \pm 0.001^{\mathrm{a}}$ & $0.003 \pm 0.002^{\mathrm{a}}$ \\
\hline
\end{tabular}

Data are presented as means \pm standard deviations $(S D)(n=3)$. Values in the same row followed by similar letters are not significantly different by Independent sample t-test $(\alpha=5 \%)$.

Table 2. Nutrition and minerals composition of A. bilimbi leaves powder.

\begin{tabular}{lcc}
\hline \multicolumn{1}{c}{ Constituent } & Amount & Unit \\
\hline Moisture & $5.58 \pm 0.11$ & $\%$ \\
Ash & $5.71 \pm 0.06$ & $\% \mathrm{dwt}$ \\
Protein & $13.67 \pm 0.19$ & $\% \mathrm{dwt}$ \\
Lipid & $4.64 \pm 0.01$ & $\% \mathrm{dwt}$ \\
Carbohydrates & $70.40 \pm 0.37$ & $\% \mathrm{dwt}$ \\
Minerals: & & \\
Iron $(\mathrm{Fe})$ & $85.46 \pm 9.79$ & $\mu \mathrm{g} / \mathrm{mL}$ \\
Sodium $(\mathrm{Na})$ & $81.09 \pm 0.09$ & $\mu \mathrm{g} / \mathrm{mL}$ \\
Calcium $(\mathrm{Ca})$ & $13.56 \pm 2.99$ & $\mathrm{mg} / \mathrm{mL}$ \\
Potassium $(\mathrm{K})$ & $110.69 \pm 7.39$ & $\mathrm{mg} / \mathrm{mL}$ \\
Magnesium $(\mathrm{Mg})$ & $448.45 \pm 21.44$ & $\mu \mathrm{g} / \mathrm{mL}$ \\
\hline
\end{tabular}

Data are expressed as mean \pm standard deviation $(n=3)$. dwt: dry weight

The yields of A.bilimbi leaves of ethanolic extract were higher (50.87\%) than water extract (43.28\%). Ethanol extract showed a higher total solid $\left(18.40^{\circ} \mathrm{Brix}\right)$ than water extract $\left(0.5^{\circ} \mathrm{Brix}\right)$. In the case of total acid titration, ethanol extract also showed a higher value $(0.0086 \%)$ than those in water extract $(0.0066 \%)$, this might be caused by the polar hydroxyl group and the non-polar alkyl group in ethanol. These groups might catch more dissolved solids than water solvent and caused the higher yield than those water extract. This result was in line with Verdiana et al. (2018) that extracted lemon peel with different extracting solvents and the results showed ethanol exhibited the highest yield.

Table 1 shows that according to the colour difference analysis, the $L^{*}$ value of $A$. bilimbi dried extract was $47.872-56.897$ that represented dark less $a^{*}$ value was -3.717 to -1.221 that means tended to red colour and the $b^{*}$ value (yellowish level) was $10,373-16.419$ that indicated inclined to yellow colour. Moreover, the hue A. bilimbi leaves dried extracts was 0.002 0.003 , which means it shows red colour.

The chlorophyll content of the leaves can influence the brightness of $A$. bilimbi leaves. The darker the color of A. bilimbi leaves could be interpreted that the higher the chlorophyll content. This red $a^{\star}$ value can indicate the presence of alkaloid and phenol compounds, where both compounds are active compounds that have orange, red, brownish-red and brown pigments (Şevik et al., 2014). The trend of the yellow colour can show the presence of flavonoid compounds, where the flavonoid compound is an active compound that has a yellow pigment, yellow-orange to orange (Triyono et al., 2019). The dried leaves of A. bilimbi tend yellow colour. It represents the presence of flavonoid compounds, where flavonoid compounds are active compounds that have yellow, orange to orange pigments (Wan et al., 2019). Based on the colour analysis that showed the yellow dark of $A$. bilimbi extract, this study suggested to use A. bilimbi leaves as food dyes and herbal tea.

Five essential minerals for human were quantified from A. bilimbi leaves powder. The results showed that potassium $(110.69 \mathrm{mg} / \mathrm{mL})$ was the highest amount of mineral (Table 2). Moreover, it also contained calcium $(13.56 \mathrm{mg} / \mathrm{mL})$, iron $(85.46 \mu \mathrm{g} / \mathrm{mL})$, sodium $(81.09 \mu \mathrm{g} / \mathrm{mL})$, and magnesium $(448.45 \mu \mathrm{g} / \mathrm{mL})$. There is no comparative information that could be conveyed from other references regarding to the nutritional component of $A$. bilimbi leaves powder.

Additionally, from proximate analysis, A. bilimbi leaves powder possessed a higher carbohydrates contents than protein, lipid, moisture, and ash. Compared to nutritional value of A. bilimbi fruit that contained 94.2-94.7 g moisture, $0.61 \mathrm{~g}$ protein, $0.6 \mathrm{~g}$ fiber, $0.31 \mathrm{~g}$ ash, $0.40 \mathrm{~g}$ calcium, $3.4 \mathrm{~g}$ phosphorus, $11.1 \mathrm{mg}$ iron, $1.01 \mathrm{mg}$ carotene, $148 \mathrm{mg}$ potassium, $0.01 \mathrm{mg}$ riboflavin, and $0.30 \mathrm{mg}$ ascorbic acid in $100 \mathrm{~g}$ (Kumar et al., 2013), our results showed significantly different. The leaves and fruits of $A$. bilimbi have been traditionally used to control hypertension. Its leaves extract show significant antihypertensive effect (Bipat et al., 2008). For the body, potassium is a mineral associated with controlling and reducing blood pressure. Sodium is a mineral that is associated with blood fluid, potassium liquid in white blood cells, and liquid sodium in cells (Susanti, 2017).

\subsection{Total phenolic contents (TPC), total flavonoids contents (TFC), and antioxidant activity of $A$. bilimbi}

The total phenolic contents (TPC), total flavonoid contents (TFC), and antioxidant activity of $A$. bilimbi leaves extracts are presented in Table 3. Ethanol extract exhibited a significantly higher value in total phenols (53.55 mg GAE/g), flavonoids (29.71 mg QE/g), and antioxidant activity (82.82 mg GAE/g) compared to those in water extract.

In the total phenols, flavonoids, and antioxidant activity, our results are similar with the previous study (Rahman et al., 2014) that reported the ethanol extract of $A$. bilimbi leaves had a total phenolic contents and a total flavonoid contents were $38.78 \mathrm{mg}$ $\mathrm{GAE} / \mathrm{g}$, and $1.67 \mathrm{mg} \mathrm{QE} / \mathrm{g}$, respectively. Additionally, according to (Fidrianny et al., 2018) report, the total of phenolic and flavonoid

Table 3. TPC, TFC and antioxidant activity of $A$. bilimbi leaves extracts.

\begin{tabular}{lccc}
\hline \multicolumn{1}{c}{ Samples } & $\begin{array}{c}\text { TPC } \\
(\mathrm{mg} \mathrm{GAE} / \mathrm{g})\end{array}$ & $\begin{array}{c}\text { TFC } \\
(\mathrm{mg} \mathrm{QE} / \mathrm{g})\end{array}$ & $\begin{array}{c}\text { Antioxidant } \\
\text { Activity } \\
(\mathrm{mg} \mathrm{GAE} / \mathrm{g})\end{array}$ \\
\hline Water extract & $35.68 \pm 4.87^{\mathrm{b}}$ & $8.88 \pm 1.14^{\mathrm{b}}$ & $42.01 \pm 4.53^{\mathrm{b}}$ \\
Ethanol extract & $53.55 \pm 5.11^{\mathrm{a}}$ & $29.71 \pm 4.66^{\mathrm{a}}$ & $82.82 \pm 1.06^{\mathrm{a}}$ \\
\hline
\end{tabular}

Data are presented as means \pm standard deviations $(S D)(n=3)$. TPC $=$ total phenolics content. TFC $=$ Total flavonoids content. $\mathrm{GAE}=$ gallic acid equivalent. $\mathrm{QE}=$ quercetin equivalent. Values in the same column followed by similar letters are not significantly different by Independent sample t-test ( $\alpha=5 \%)$. 
contents of $A$. bilimbi leaves extracted by using $\mathrm{n}$-hexane, ethyl acetate, and ethanol were $2.95,11.48$, and $11.43 \mathrm{~g} \mathrm{GAE} / 100 \mathrm{~g} \mathrm{DW}$, respectively, and 1.68, 6.51, and $2.21 \mathrm{~g} \mathrm{QE} / 100 \mathrm{~g} \mathrm{DW}$, respectively. In line with the total phenols and flavonoid contents, ethanol extract of A. bilimbi leaves gave significantly effects in DPPH scavenging activity $(\mathrm{p}<0.05)$ as compared to water extract. These results might be caused by different polarities of water and ethanol. Ethanol has been reported to have more ability to catch more active compounds, specially phenolic group, than water (Moo-Huchin et al., 2019; Ismail et al., 2019). While, water is the best solvent to catch sugar component that most give no effect on biological activity assay (Van et al., 2018). Ethanol showed more effective to catch phenolic compounds that possessed antioxidant activity than water solvent.

\subsection{Antibacterial activity}

Antibacterial activity of $A$. bilimbi L. leaves extract against Salmonella sp, Escherichia coli, and Staphylococcus aureus is shown in Table 4. Generally, compared to water extract, ethanol extract gave more inihibitory effect on the growth of $E$. coli. At the dose $50 \mathrm{mg} / \mathrm{mL}$, ethanol extract caused the maximum of inhibition zone on $S$. aureus $(27.00 \mathrm{~mm})$. It showed that $S$. aureus posessess more sensititivity respond on the presence of antibacterial agent compared to Salmonella sp, and Escherichia coli. This may be due to elaboration of enzymes that possibly destroy or in activate some of the bioactive phytoconstituents in A.bilimbi leaves. In addition, the complex nature of the cell envelope of gram-negative bacteria has been observed to retard or prevent the passage of many antimicrobial agents through the cell wall (Abubakar, 2009). Although ethanol extract showed antibacterial activity, compared to positive controls (cefadroxil and amoxilin), its inhibitory level was still lower.

In antibacterial assay, ethanol extract showed more inhibitory effects against the growth of Salmonella sp, Escherichia coli, and Staphylococcus aureus. These results are in agreement with the previous study (Kumar et al., 2013) that reported aqueous extract of $A$. Bilimbi leaves demonstrated inhibitory effect against some Gram-positive and Gram-negative bacteria including $S$. aureus, S. epidermis, B. cereus, C. diphteriae, K. rhizophila, S. typhi, C. fuendii and A. Hydrophila at the dose of $100 \mathrm{mg} / \mathrm{mL}$. Similiarly for ethanol extract, the inhibitory effects on the growth of some phatogenic bacteria such as cereus, B. megaterium, E. coli, P. aeroginosa, A. ochraceous and C. neoformans have been reported (Alhassan \& Ahmed, 2016).

Table 4. Antibacterial activity of A. bilimbi leaves extracts.

\begin{tabular}{|c|c|c|c|c|}
\hline \multirow{2}{*}{ Samples } & \multirow{2}{*}{$\begin{array}{c}\text { Concentration } \\
(\mathrm{mg} / \mathrm{mL})\end{array}$} & \multicolumn{3}{|c|}{ Inhibition zone $(\mathrm{mm})$} \\
\hline & & Salmonella sp. & E. coli & S. aureus \\
\hline $\begin{array}{l}\text { Water } \\
\text { extract }\end{array}$ & 50.00 & $9.00 \pm 1.73 a$ & $7.67 \pm 0.58 b$ & $23.33 \pm 5.03 a$ \\
\hline $\begin{array}{l}\text { Ethanol } \\
\text { extract }\end{array}$ & 50.00 & $10.33 \pm 1.53 a$ & $10.33 \pm 1.16 a$ & $27.00 \pm 1.73 a$ \\
\hline Cefadroxil $^{*}$ & 3.80 & $27.33 \pm 4.62$ & $23.33 \pm 7.64$ & $21.17 \pm 5.06$ \\
\hline Amoxilin* & 3.80 & $12.5 \pm 2.50$ & $20.00 \pm 6.57$ & $16.00 \pm 2.00$ \\
\hline
\end{tabular}

Data are presented as means \pm standard deviation (SD). Values in the same column followed by similar letters are not significantly different by Independent sample t-test $(\alpha=5 \%){ }^{*}=$ positive control for antibacterial assay.
The antibacterial potential of $A$. bilimbi leaves extracts might be due to the presence of various phytochemicals such as saponins, coumarins, flavonoids, quinone, and anthocyanins as reported previously (Abraham, 2016; Seebaluck-sandoram et al., 2019). Additionally, polyphenol contents of A. bilimbi leaves could contributed on its antibacterial activity. The inhibitory effect on the growth of bacteria by phenolic compounds might be induced iron deprivation or hydrogen bonding with vital proteins such as microbial enzymes (Aziz et al., 2014). The inhibitory zones caused by ethanol extract on $S$. aureus (Gram-positive) bacteria was higher than those Gram-negative bacteria (E. coli and Salmonella sp.) $(p<0.05)$. The ethanol extract of A. bilimbi leaves showed more inhibitory effects on Gram-negative bacteria.

\subsection{Fourier transforms infrared spectrophotometer (FTIR)}

In this study, the FTIR analyses were conducted to evaluate the active functional group from leaves powder, water extract, and ethanol extract of $A$. bilimbi. The functional groups of A. bilimbi leaves extract are shown in Table 5 .

Based on the FTIR spectrum, it shows that there is a range of hydroxyl groups $(\mathrm{O}-\mathrm{H})$ with high intensity at a wavelength of $3282.29-3337.93 / \mathrm{cm}$ (Table 5). Moreover, Table 5 shows that a wavelength number of $2912.90-2920.19 / \mathrm{cm}$ was associated with the existence of the alkane group $(\mathrm{C}-\mathrm{H})$. This wavelength number is a stretching vibration of $\mathrm{C}-\mathrm{H}$ at $\mathrm{CH}_{3}$ that strengthened by a wave length number $2846.26-2851.23 / \mathrm{cm}$ based on reference. The ethanol extract showed an intensity that was not found in those of leaves powder. This extract also showed a peak at wave number $1736.77 / \mathrm{cm}$ where the peak at this wavelength was not found in the leaves powder and water extract. The functional group contained in this wavelength number is $\mathrm{C}=\mathrm{O}$. The spectrum results show uptake at wavelength numbers $1602.82-1635.99 / \mathrm{cm}$. The ethanol and water extracts showed relatively a higher intensity than those of leaves powder at this wavenumber. The functional group in the range of wavenumbers is $\mathrm{C}=\mathrm{O}$. There is absorption on the spectrum results at wavelength number $1028-1255.57 / \mathrm{cm}$. Peak was formed sharply in the three samples (leaves powder,

Table 5. The functional group of Averrhoa bilimbi leaves extracts.

\begin{tabular}{cccccc}
\hline $\begin{array}{c}\text { Wavelength } \\
\text { number }(/ \mathrm{cm})\end{array}$ & $\begin{array}{c}\text { Wavelength } \\
\text { References } \\
(/ \mathrm{cm})\end{array}$ & $\begin{array}{c}\text { Peak } \\
\text { form }\end{array}$ & $\begin{array}{c}\text { Functional } \\
\text { group }\end{array}$ & $\begin{array}{c}\text { Type of } \\
\text { compounds }\end{array}$ \\
\hline $3282.29-3337.93$ & $3200-3600$ & Wide & O-H & $\begin{array}{c}\text { Phenolic } \\
(\mathrm{O}-\mathrm{H} \text { bond }), \\
\text { monomer } \\
\text { alcohol } \\
\text { Alkane }\end{array}$ \\
1736.77 & $2850-2970$ & Sharp & C-H & $\begin{array}{c}\text { Aldehyd, } \\
\text { ketone, }\end{array}$ \\
$1602.82-1635.99$ & $1610-1680$ & Sharp & C=C & C=O & $\begin{array}{c}\text { Alkena } \\
\text { carboxylate acid, } \\
\text { ester } \\
1028-1255.57\end{array}$ \\
& $1050-1300$ & Sharp & C-O & $\begin{array}{c}\text { Alcohol, ether, } \\
\text { carboxylate acid, } \\
\text { ester }\end{array}$ \\
\hline
\end{tabular}

Source: Skoog et al. (1998). 
water extract, or ethanol extract), its means that the three sample possessed functional group of C-O.

In the FTIR analysis, ethanol extract of $A$. bilimbi leaves showed more intensity in wavelength number $3282.29-3337.93 / \mathrm{cm}$ that represented phenolic bound $(\mathrm{OH})$. FTIR spectra have physical characteristics and unique characteristics so that different compounds will have different spectra, and the possibility of two compounds having the same spectra is less likely (MierzwaHersztek et al., 2019). The area of the main functional group ranged 4000-1500/cm wave number adsorption, while for fingerprint area is at $500-1500 / \mathrm{cm}$. For adsorption of $1500-500 / \mathrm{cm}$, it is difficult to identify a detected compound due to each compound gives a different pattern in this area (Dachriyanus, 2004). The spectrum of FTIR analysis can be influenced by the extraction method by maceration and the use of solvents for polar extraction, which can affect the absorption of O-H groups. These results were in agreement with (Putra, 2016) that reported the maceration method of $A$. bilimbi leaves could separated the highest amount of tannin compounds compared to other methods. Tannins are compounds that have many $\mathrm{O}-\mathrm{H}$ bonds so that the results of the spectrum show the absorption of $\mathrm{O}-\mathrm{H}$ groups with reasonably high intensity.

\section{Conclusion}

Based on above results, we found that the A. bilimbi leaves powder was rich of nutrient contents which carbohydrate was the highest content. Ethanol and water solvents gave negligible effects on the physical characteristics ( $\mathrm{pH}$ and total acids) of A. bilimbi dried extracts. In mineral content analysis, potassium was detected as the major mineral content of the leaves powder. Compared to water extract, ethanol extract of $A$. bilimbi leaves demonstrated more inhibitory effects on antioxidant and antibacterial activities and it is proportional with the content of total phenols and flavonoids. Among of the functional group detected, hydroxyl (O-H) that might be belonging to phenolic group, showed more intensity in ethanol extract compared those in water extract. The color analysis demonstrated that the more yellow color in a leaves powder of A. bilimbi associated with the presence of flavonoids, a class of phenolic group. However, to detect the presence of active chemical group in A. bilimbi leaves required further analyses using different tools such as gas chromatography-mass spectrometry (GC-MS), or liquid chromatography- mass spectrometry (LC-MS).

\section{References}

Abraham, C. (2016). Antibacterial effects of Averrhoa Bilimbi L. fruit extracts. International Research Journal of Biological Sciences, 5, 72-74.

Abubakar, E.-M. M. (2009). Efficacy of crude extracts of garlic (Allium sativum Linn.) against nosocomial Escherichia coli, Staphylococcus aureus, Streptococcus pneumoniea and Pseudomonas aeruginosa. Journal of Medicinal Plants Research, 3(4), 179-185.

Alhassan, A., \& Ahmed, Q. (2016). Averrhoa bilimbi Linn.: A review of its ethnomedicinal uses, phytochemistry, and pharmacology. Journal of Pharmacy \& Bioallied Sciences, 8(4), 265-271. PMid:28216948.

Andriana, Y., Xuan, T. D., Quy, T. N., Minh, T. N., Van, T. M., \& Viet, T. D. (2019a). Antihyperuricemia, antioxidant, and antibacterial activities of tridax procumbens 1 . Foods, 8(1), 21. http://dx.doi. org/10.3390/foods8010021. PMid:30634624.
Andriana, Y., Xuan, T., Quy, T., Tran, H., \& Le, Q.-T. (2019b). Biological activities and chemical constituents of essential oils from Piper cubeba Bojer and Piper nigrum L. Molecules, 24(10), 95-99. http:// dx.doi.org/10.3390/molecules24101876. PMid:31096694.

Association of Official Analytical Chemist - AOAC. (1990). Official Methods of Analysis. Arlington, Virginia: AOAC.

Aziz, M. A., Rahman, S., Islam, M., \& Begum, A. (2014). A comparative study on antibacterial activities ans cytotoxic properties of various leaves extracts of averrhoa bilimbi. International Journal of Pharmaceutical Sciences and Research, 5, 913-918.

Bipat, R., Toelsie, J., Joemmanbaks, R., Gummels, J., Klaverweide, J., Jhanjan, N., Orie, S., Ramjiawan, K., Soekhoel, R.C., \& Mans, R. A. (2008). Effects of plants popularly used against hypertension on norepinephrine-stimulated guinea pig atria. Pharmacognosy Magazine, 4, 12-19.

Chan, E. W. C., Tie, P. P., Soh, E. Y., \& Law, Y. P. (2011). Antioxidant and antibacterial properties of green, black, and herbal teas of Camellia Sinensis. Pharmacognosy Research, 3(4), 40-49. http:// dx.doi.org/10.4103/0974-8490.89748. PMid:22224051.

Dachriyanus. (2004). Spectroscopic analysis of the structure of organic compounds. (U. A. Padang ed.). Institute for Information and Communication Technology Development (LPTIK).

Ernawati, R. (2016). Study of Averrhoa bilimbi leaf extract as an antibacterial in edible coating to prolong the shelf life of tomatoes (Lycopersium esculentum). Yogyakarta: Muhammadiyah University.

Fidrianny, I., Rahmawati, A., \& Hartati, R. (2018). Comparison profile of different extracts of Averrhoa Bilimbi L. in Antioxidant Properties and phytochemical content. Rasayan Journal of Chemistry, 11(4), 1628-1634. http://dx.doi.org/10.31788/RJC.2018.1143091.

Ismail, B. B., Pu, Y., Guo, M., Ma, X., \& Liu, D. (2019). LC-MS/QTOF identification of phytochemicals and the effects of solvents on phenolic constituents and antioxidant activity of baobab (Adansonia digitata) fruit pulp. Food Chemistry, 277, 279-288. http://dx.doi. org/10.1016/j.foodchem.2018.10.056. PMid:30502146.

Iwansyah, A., Julianti, W., \& Luthfiyanti, R. (2019). Characterization of nutrition, antioxidant properties, and toxicity of Physalis Angulata L. Plant Extract. Asian J Pharm Clin Res, 12(11), 95-99. http://dx.doi. org/10.22159/ajpcr.2019.v12i11.35497.

Jones, P. J., \& Jew, S. (2007). Functional food development: concept to reality. Trends in Food Science \& Technology, 18(7), 387-390. http:// dx.doi.org/10.1016/j.tifs.2007.03.008.

Kumar, K. A., Gousia, S., Anupama, M., \& Latha, J. N. (2013). Review Article: A review on phytochemical constituents and biological assays of averrhoa bilimbi. International Journal of Pharmacy and Pharmaceutical Science Research, 3, 136-139.

Kumaran, R. J., \& Karunakaran, R. J. (2007). Antioxidant and free radical scavenging activity of an aqueous extract of Coleus aromaticus. Food Chemistry, 97(1), 109-114. http://dx.doi.org/10.1016/j. foodchem.2005.03.032.

Kurian, A.J., Geetha, G., \& Thavamani, B.S. (2018). Isolation and characterization of an isolated flavonoid from Averrhoa bilimbi. Asian Journal of Chemical Sciences, 5(1), 1-8.

López-López, A., Moreno-Baquero, J. M., \& Garrido-Fernández, A. (2020). In Vitro Bioaccessibility of Ripe Table Olive Mineral Nutrients. Foods, 9(3), 275. http://dx.doi.org/10.3390/foods9030275. PMid:32138211.

Meda, A., Lamien, C. E., Romito, M., Millogo, J., \& Nacoulma, O. G. (2005). Determination of the total Phenolic, Flavonoid and Proline Contents in Burkina Fasan Honey, as well as their radical scavenging activity. Food Chemistry, 91(3), 571-577. http://dx.doi.org/10.1016/j. foodchem.2004.10.006. 
Mierzwa-Hersztek, M., Gondek, K., Nawrocka, A., Pińkowska, H., Bajda, T., Stanek-Tarkowska, J., \& Szostek, M. (2019). FT-IR analysis and the content of phenolic compounds in exogenous organic matter produced from plant biomass. Journal of Elementology, 24(3), 879896. http://dx.doi.org/10.5601/jelem.2018.23.3.1716.

Miraj, A., Kabir, A., Mamun, Y., Akhter, S., Ahammed, M., Sultana, S., Hakim, M., Sultana, F., Alam, M., Mohammad, M., \& Hossain, M. (2019). Evaluation of the analgesic and anti-inflammatory activities of methanolic extracts of the leaves of Averrhoa bilimbi leaves. Discovery Phytomedicine, 6(1), 12-15. http://dx.doi.org/10.15562/ phytomedicine.2019.77.

Moo-Huchin, V. M., Canto-Pinto, J. C., Cuevas-Glory, L. F., Sauri-Duch, E., Pérez-Pacheco, E., \& Betancur-Ancona, D. (2019). Effect of extraction solvent on the phenolic compounds content and antioxidant activity of Ramon nut (Brosimum alicastrum). Chemical Papers, 73(7), 1647-1657. http://dx.doi.org/10.1007/s11696-019-00716-x.

Pendit, P., Zubaidah, E., \& Sriherfyna, F. (2016). Physicochemical characteristics and antibacterial activity of Averrhoa bilimbi L. leaf extract. Agroindustry and Food, 4(1), 400-409.

Putra, Y. (2016). The influence of Averrhoa bilimbi L. extraction method as green corrosion inhibitor on $5 \mathrm{~L}$ grade B fire steel in $3.5 \% \mathrm{NaCl}$ environment. Surabaya: ITS University.

Rahman, M. M., Habib, M. R., Hasan, M. A., Al Amin, M., Saha, A., \& Mannan, A. (2014). Comparative assessment on in vitro antioxidant activities of ethanol extracts of Averrhoa bilimbi, Gymnema sylvestre and Capsicum frutescens. Pharmacognosy Research, 6(1), 36-41. http://dx.doi.org/10.4103/0974-8490.122915. PMid:24497740.

Rice-Evans, C., Miller, N., \& Paganga, G. (1997). Antioxidant properties of phenolic compounds. Trends in Plant Science, 2(4), 152-159. http://dx.doi.org/10.1016/S1360-1385(97)01018-2.

Sales, M. E., Andaya, A. J., \& Maylas, P. D. (2018). Averrhoa bilimbi extract as an alternative anticoagulant for manual complete blood count. Journal of Health Sciences, 1(1), 38-43.

Saputra, O., \& Anggraini, N. (2016). Efficacy of Averrhoa bilimbi L. on healing Acne Vulgaris. Majority, 5(1), 76-80.
Seebaluck-Sandoram, R., Lall, N., Fibrich, B., Blom van Staden, A., Saleem, H., \& Mahomoodally, M. F. (2019). Biocatalysis and Agricultural Biotechnology Antimicrobial, antioxidant and cytotoxic evaluation of two underutilised food plants: Averrhoa bilimbi L. (Oxalidaceae) and Phyllanthus acidus L. Skeels (Phyllanthaceae). Biocatalysis and Agricultural Biotechnology, 18, 1-6. http://dx.doi. org/10.1016/j.bcab.2019.01.036.

Şevik, H., Belkayalı, N., \& Aktar, G. (2014). Change of Chlorophyll amount in some landscape plants. Journal of Biotechnological Sciences. 2(1), 10-16.

Skoog, D., Holler, F., \& Nieman, T. (1998). Principles of instrumental analysis (5th ed.). Orlando: Hourcourt Brace.

Susanti, M. R. (2017). The relationship of sodium and potassium intake with blood pressure in the elderly in the village of Pajang. Surakarta: Muhammadiyah University.

Triyono, A., Luthfiyanti, R., Rahman, T., \& Pamungkas, N. (2019, October 23-24). The effects of solvents and maltodekstrin on the characteristics of Physalis angulata L. leaf extract. In International Conference on Natural Products and Bioresourch Sciences. IOP Conf. Series: Earth and Environmental Science, Tangerang, Indonesia: IOP Publishing.

Van, T. M., Xuan, T. D., Minh, T. N., \& Quan, N. V. (2018). Isolation and purification of potent growth inhibitors from Piper methysticum root. Molecules (Basel, Switzerland), 23(8), 1907. http://dx.doi. org/10.3390/molecules23081907. PMid:30065174.

Verdiana, M., I.W. R. Widarta, I.D.G.M. Permana. (2018). Effect of Solvent Type in Ultrasonic Assisted Extraction on Antioxidant Activity of Lemon Peel (Citrus limon (Linn.) Burm F.). Jurnal Ilmu dan Teknologi Pangan, 7(4), 213-222.

Wan, H., Yu, C., Han, Y., Guo, X., Luo, L., Pan, H., Zheng, T., Wang, J., Cheng, T., \& Zhang, Q. (2019). Determination of flavonoids and carotenoids and their contributions to various colors of rose cultivars (Rosa spp.). Frontiers of Plant Science, 10(February), 1-14. http:// dx.doi.org/10.3389/fpls.2019.00123. PMid:30809238.

Waterman, P., \& Mole, S. (1994). Analysis of Phenolic Plant Metabolite. Oxford: Blackwell Scientific. 